\title{
Research Status and Prospect on Vanadium-Based Catalysts for $\mathrm{NH}_{3}$-SCR Denitration
}

\author{
Jie Zhang, Xiangcheng Li *(D), Pingan Chen * ${ }^{*}$ and Boquan Zhu* \\ The State Key Laboratory of Refractories and Metallurgy, Wuhan University of Science and Technology, \\ Wuhan 430081, China; zzzjwust@163.com \\ * Correspondence: lixiangcheng@wust.edu.cn (X.L.); cpa_0502@163.com (P.C.); zbqref@263.net (B.Z.)
}

Received: 27 June 2018; Accepted: 3 September 2018; Published: 6 September 2018

\begin{abstract}
Selective catalytic reduction of $\mathrm{NO}_{x}$ with $\mathrm{NH}_{3}$ is one of the most widely used technologies in denitration. Vanadium-based catalysts have been extensively studied for the deNO $\mathrm{N}_{\mathrm{x}}$ process. $\mathrm{V}_{2} \mathrm{O}_{5} / \mathrm{WO}_{3}\left(\mathrm{MoO}_{3}\right) \mathrm{TiO}_{2}$ as a commercial catalyst has excellent catalytic activity in the medium temperature range. However, it has usually faced several problems in practical industrial applications, including narrow windows of operation temperatures, and the deactivation of catalysts. The modification of vanadium-based catalysts will be the focus in future research. In this paper, the chemical composition of vanadium-based catalysts, catalytic mechanism, the broadening of the temperature range, and the improvement of erosion resistance are reviewed. Furthermore, the effects of four major systems of copper, iron, cerium and manganese on the modification of vanadium-based catalysts are introduced and analyzed. It is worth noting that the addition of modified elements as promoters has greatly improved the catalytic performance. They can enhance the surface acidity, which leads to the increasing adsorption capacity of $\mathrm{NH}_{3}$. Surface defects and oxygen vacancies have also been increased, resulting in more active sites. Finally, the future development of vanadium-based catalysts for denitration is prospected. It is indicated that the main purpose for the research of vanadium-based modification will help to obtain safe, environmentally friendly, efficient, and economical catalysts.
\end{abstract}

Keywords: vanadium-based catalysts; $\mathrm{NH}_{3}-\mathrm{SCR} ; \mathrm{NO}_{\mathrm{x}}$; modification

\section{Introduction}

Nitrogen oxides $\left(\mathrm{NO}_{\mathrm{x}}\right)$ are one of major air pollutants that could cause great harm to the ecological environment and human health. How to remove $\mathrm{NO}_{\mathrm{x}}$ effectively is a significant issue of environmental protection. Currently, there are three kinds of reductant for the selective catalytic reduction of $\mathrm{NO}_{\mathrm{x}}$ : $\mathrm{NH}_{3}$, Urea and $\mathrm{HC}$. $\mathrm{NH}_{3}-\mathrm{SCR}$ (selective catalytic reduction with ammonia) is the most mature industrial technology at present, and its main reaction process [1-3] is:

$$
\begin{gathered}
4 \mathrm{NH}_{3}+4 \mathrm{NO}+\mathrm{O}_{2} \rightarrow 4 \mathrm{~N}_{2}+6 \mathrm{H}_{2} \mathrm{O} \text { (standard SCR reaction) } \\
4 \mathrm{NH}_{3}+2 \mathrm{NO}+2 \mathrm{NO}_{2} \rightarrow 4 \mathrm{~N}_{2}+6 \mathrm{H}_{2} \mathrm{O} \text { (fast SCR reaction) }
\end{gathered}
$$

The technology has been used in hundreds of large power plants in the United States, Germany, and Japan. Environmental conditions have a great impact on this technology. For example, it is important to control oxygen content of the exhaust appropriately for $\mathrm{NH}_{3}$-SCR. In the absence of $\mathrm{O}_{2}$, the reducing agent cannot reduce NO. When the oxygen content of the exhaust is below $5 \%$, the catalytic reduction reaction of $\mathrm{NH}_{3}$ can be carried out to convert $\mathrm{NO}_{x}$ into $\mathrm{N}_{2}$ and $\mathrm{H}_{2} \mathrm{O}$. When the oxygen concentration is too high, the activity of the catalyst will be reduced, and $\mathrm{NH}_{3}$ will be oxidized to $\mathrm{NO}_{2}$, resulting in new pollution. 
The catalyst is the key to determining the reactivity of $\mathrm{NH}_{3}-\mathrm{SCR}$ under the proper external conditions. In the 1960s, a study on exhaust gas-purifying catalysts was started. A three-way catalyst (TWC) consisting of precious metals was researched in the initial stage. Although the catalytic effect is ideal, considering the cost and the source of precious metals, the direction has shifted to transition metal oxide catalysts. Vanadium-based catalysts are used due to the high activity of SCR reactions. With the continuous improvement of environmental protection and energy awareness and the increasing demand for low $\mathrm{NO}_{x}$ emissions, the traditional vanadium-based catalysts are no longer satisfactory. The performance improvement of vanadium-based catalysts has become the focus of research.

In this paper, the characteristics and performance improvement of vanadium-based catalysts is the main line. The research progress of vanadium-based catalysts at home and abroad is reviewed. The advantages and disadvantages, mechanism, and improvement methods are summarized. The development of vanadium-based catalysts for denitrification is prospected.

\section{Composition of Vanadium Based Catalyst}

The catalyst is obtained in such a way that the active component and promoter are loaded on catalyst support. The catalyst support is believed to be important for SCR reaction because of its high surface areas, good thermal stability, and high active substance dispersion on surfaces [4]. In general, $\mathrm{TiO}_{2}$-anatase is widely used as a support for vanadium-based catalyst because of its great $\mathrm{SO}_{2}$ resistance and excellent dispersion of $\mathrm{V}_{2} \mathrm{O}_{5}$. A small amount of sulfate species loaded on the support enhances the surface acidity of the $\mathrm{V}_{2} \mathrm{O}_{5} / \mathrm{TiO}_{2}$ catalyst, increases the amount of adsorbed $\mathrm{NH}_{3}$, and improves the $\mathrm{SCR}$ activity $[5,6]$. However, pure $\mathrm{TiO}_{2}$ is poorly active during the $\mathrm{SCR}$ reaction due to its weak acidity and poor redox ability. Additionally, $\mathrm{TiO}_{2}$ will transform from anatase to rutile at high temperatures, which will affect the stability of the support. Therefore, some modifications have been investigated to overcome these defects. Adrian, $\mathrm{M}$. et al. [7] chose $\mathrm{TiO}_{2}-\mathrm{WO}_{3}-\mathrm{SiO}_{2}$ as a catalyst support for optimization, using rare metal to inhibit the phase transition of titanium dioxide, to avoid high temperature sintering and surface area loss, and improve the structural strength of the support. At the same time, $\mathrm{SiO}_{2}$ is beneficial to $\mathrm{SO}_{2}$ resistance. Cheng, J. et al. [8] synthesized $\mathrm{TiO}_{2}-\mathrm{PILC}$ as a catalyst support for the $\mathrm{SCR}$ of $\mathrm{NO}_{\mathrm{x}}$ with $\mathrm{NH}_{3}$ due to pillared interlayered clays' large specific surface areas, acidity, and high thermal stability. Other catalyst support is also helpful for the performance of the catalyst, such as $\mathrm{TiO}_{2}$-pal [4], and activated carbon (AC) [9].

The active component is the dominant factor affecting vanadium-based catalyst performance, and it can be divided into single vanadium oxide $\mathrm{VO}_{x}[10,11]$ and multi-metal oxide compounds such as $\mathrm{VO}_{\mathrm{x}}-\mathrm{WO}_{3}$ [12], $\mathrm{VO}_{\mathrm{x}}-\mathrm{CeO}_{\mathrm{x}}[8] . \mathrm{V}_{2} \mathrm{O}_{5}$ catalyst is a kind of structure-sensitive catalyst, whose activity is affected by the structure and coverage of $\mathrm{V}_{2} \mathrm{O}_{5}$, the crystal form of catalyst support, and the modification element. Increasing the amount of $\mathrm{V}_{2} \mathrm{O}_{5}$ added can help to improve the catalytic activity. However, $\mathrm{V}_{2} \mathrm{O}_{5}$ will promote the transformation of anatase to rutile, which is not conducive to the thermal stability of the catalyst, resulting in the shortened life of the catalyst and the decrease of selectivity [13]. In view of this, the content of vanadium in the commercial catalyst $\mathrm{VO}_{x}-\mathrm{WO}_{x} / \mathrm{TiO}_{2}$ is generally limited to less than $2.6 \%$. The coverage rate is also an important parameter, which can be adjusted by the $\mathrm{V}$ loading or the calcination temperature [14]. The coverage rate for ideal $\mathrm{V}_{2} \mathrm{O}_{5}-\mathrm{WO}_{3} / \mathrm{TiO}_{2}$ catalysts is $25-50 \%$. Below $25 \%$ indicates that the vanadium content is too low or the surface area is too high and the catalyst activity is low. With coverage of more than $50 \%$, the stability of the catalyst and the conversion of $\mathrm{NO}_{\mathrm{x}}$ at high temperatures cannot be guaranteed $[7,14]$. The vanadium coverage of conventional catalysts is below the dispersion limit that monolayer 6-7 atom $/ \mathrm{nm}^{2}$ to avoid the crystalline $\mathrm{V}_{2} \mathrm{O}_{5}$ [15]. It is generally believed that in the dry anatase surface at low loading $\mathrm{V}_{2} \mathrm{O}_{5}$, the dehydrated surface vanadium generally tend to possess isolated four-fold coordination. The isolated $\mathrm{VO}_{4}$ units consist of one terminal $\mathrm{V}=\mathrm{O}$ bond and three bridging V-O-Ti bonds, as shown in Figure 1a. As the coverage increases, the number of $\mathrm{V}-\mathrm{O}-\mathrm{V}$ bridges per $\mathrm{V}$ increases. In practical application, the vanadium species mainly exists in the form of polyvanadate, as shown in Figure $1 \mathrm{~b}$. This species has higher SCR reactivity than the 
monomer (Ti-O) $)_{3} \mathrm{~V}=\mathrm{O}[3,15,16]$. At high loading $\mathrm{V}_{2} \mathrm{O}_{5}$, crystalline vanadia is generated on sulfated $\mathrm{TiO}_{2}$ (Figure 1c). In view of the volatilization of vanadium at high temperatures, the use of metal vanadate $\left(\mathrm{MeVO}_{4}\right)$ in the active phase can increase the melting point of the catalyst $[17,18]$. Moreover, Zhou, X. et al. [19] synthesize the V@Mn-Fe/ATP catalyst with a similar core-shell structure successfully. It was found that the $\mathrm{V}_{2} \mathrm{O}_{5}$ layer as a coating might protect other active metals of the catalyst.

(a)

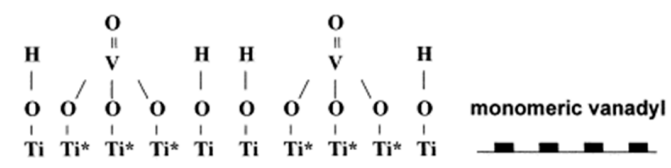

(b)

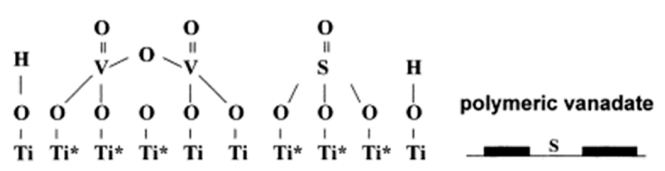

(c)

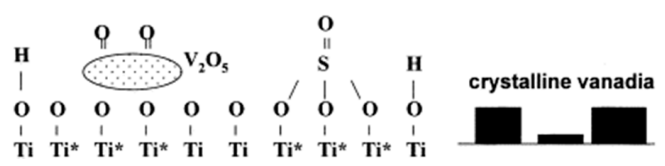

Figure 1. A schematic of the transformation of $\mathrm{V}_{2} \mathrm{O}_{5}$ on titania: (a) low loading $\mathrm{V}_{2} \mathrm{O}_{5}$ supported on sulfur-free $\mathrm{TiO}_{2}$; (b) low loading $\mathrm{V}_{2} \mathrm{O}_{5}$ supported on sulfated $\mathrm{TiO}_{2}$ and (c) high loading $\mathrm{V}_{2} \mathrm{O}_{5}$ supported on sulfated $\mathrm{TiO}_{2}\left(\mathrm{Ti}^{*}\right.$, basic site; Ti, neutral site). Reproduced with permission [20]. Copyright 2000, Elsevier.

\section{3. $\mathrm{NH}_{3}$-SCR Reaction Mechanism of Vanadium-Based Catalyst}

Zhu, M. et al. [2] used elemental tagging to study the SCR reaction pathway of vanadium-based catalysis and found that the SCR reaction occurs at the surface $\mathrm{V}^{5+} \mathrm{O}_{4}$ site. This is shown in Figure 2, which exhibits a schematic diagram of the standard SCR reaction and indicates that SCR reaction is divided into three steps. First, $\mathrm{NH}_{3}$ adsorption is observed on the surface of the acid center. Next, the adsorbed ammonia reacts with $\mathrm{NO}$ to form an intermedium. The intermedium can decompose to $\mathrm{N}_{2}$ and $\mathrm{H}_{2} \mathrm{O}$ and reduce surface $\mathrm{V}^{5+} \mathrm{O}_{4}$ sites. Finally, the reduced $\mathrm{V}^{4+} \mathrm{O}_{3}$ is reoxidized by $\mathrm{O}_{2}$. Through the kinetic study, the rate-determining step of the SCR reaction is that the $\mathrm{V}^{5+}$ on the surface is reduced to $\mathrm{V}^{4+}$ by $\mathrm{NO}$ and $\mathrm{NH}_{3}$, particularly the breaking of $\mathrm{N}-\mathrm{H}$ bonds during the process of formation or decomposition of the intermedium. The vanadium-based catalyst $\mathrm{V}_{2} \mathrm{O}_{5}-\mathrm{WO}_{3} / \mathrm{TiO}_{2}$ has been commercialized and applied in some thermal power plants. In $\mathrm{V}_{2} \mathrm{O}_{5}-\mathrm{WO}_{3} / \mathrm{TiO}_{2}$ catalysts, the $\mathrm{O}=\mathrm{VO}_{3}$ site is involved in the redox cycle, which is the most important for the SCR reaction. The $\mathrm{O}=\mathrm{WO}_{4}$ site enhances the surface acidity of the catalyst and promotes the adsorption of $\mathrm{NH}_{3}$ [12]. Tungsten oxide as a promoter has two primary roles in catalysis: it restrains the generation of bulk polymeric $\mathrm{V}$ aggregates and retains Brønsted acid sites at high temperatures [21].

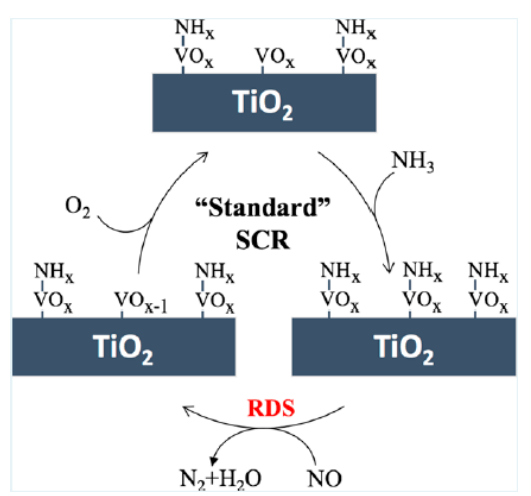

Figure 2. Schematic diagram of the standard SCR reaction. Reproduced with permission [2]. Copyright 2017, American Chemical Society. 
Although vanadium-based catalysts have been used in industrial applications, the reaction mechanism for vanadium-based catalysts remains controversial. It is mainly divided into two theories: the Langmuri-Hinshelwood theory (L-H theory) and the Eley-Rideal theory (E-R theory). It is widely believed that the vanadium-based catalyst selectively reduces $\mathrm{NO}_{\mathrm{x}}$ via the E-R mechanism at medium-high temperature. A schematic diagram of the $\mathrm{NH}_{3}-\mathrm{SCR}$ reaction mechanism is shown in Figure 3. Although ammonia is adsorbed on both Lewis acid sites and Brønsted acid sites, $\mathrm{NH}_{3}$ is more prone to be adsorbed at the Brønsted acid sites than at the Lewis acid sites. $\mathrm{NH}_{3}$ forms $\mathrm{NH}^{4+}$ on the Brønsted acid site $(\mathrm{V}-\mathrm{OH})$ and reacts with the $\mathrm{V}=\mathrm{O}$ group to generate intermediate products, and then decomposes into $\mathrm{N}_{2}$ and $\mathrm{H}_{2} \mathrm{O}$. However, $\mathrm{NH}_{3}$ adsorption on Lewis acid sites will produce $\mathrm{N}_{2} \mathrm{O}[3]$.

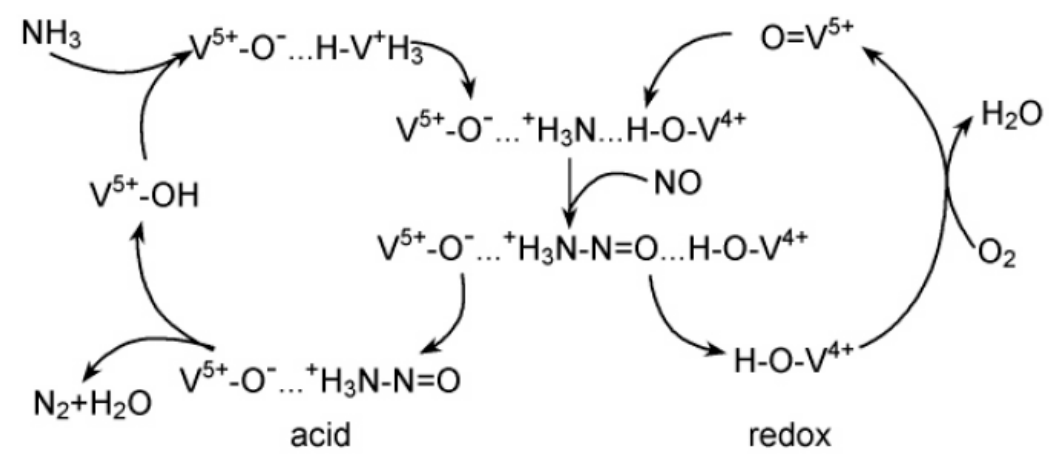

Figure 3. Schematic diagram of $\mathrm{NH}_{3}-\mathrm{SCR}$ reaction mechanism. Reproduced with permission [22]. Copyright 1995, Elsevier.

Aside from the Langmuri-Hinshelwood model and the Eley-Rideal model, a surface Mar-van Krevelen reaction mechanism has been proposed for the SCR reaction. According to the Mar-Van Krevelen mechanism, SCR reaction divides into three steps: adsorption, migration, and reoxidation. There are two different types of centers that prevail on the SCR catalysts: S1 sites, related to vanadium and its redox cycle, and S2 sites, used to store ammonia and nitrates [23]. However, there is controversy around the step of vanadium reoxidation. According to the sites of detached gaseous oxygen, two different possibilities for vanadium reoxidation steps were proposed: in one case that the vacancy in the vanadia lattice is filled using molecular oxygen, and the other through the creation of a vacancy in the titania lattice [24].

In fact, the SCR reaction mechanism is closely related to the reaction temperature. With different reaction temperatures, the number and distribution of the active sites of the catalysts are different, and the types, quantities and distributions of the acids are not the same. Therefore, the reaction mechanism of vanadium-based catalysts may also change with different reaction temperatures. It is worth noting that current studies only focus on the formation of acid centers and the activity of acids in acid-base mechanism. It also has a certain significance to study the effect of alkaline position on the adsorption and the activity [3].

\section{Performance Improvement of Vanadium Based Catalysts}

Commercial vanadium-based catalysts are widely used in industry due to their high activity and excellent $\mathrm{SO}_{2}$ resistance. However, they have a narrow activity window, and weak ability for resisting $\mathrm{VO}_{\mathrm{X}}$ species to thermal sintering. The metal oxide is also over-oxidized, which not only oxidizes $\mathrm{NH}_{3}$ to $\mathrm{N}_{2} \mathrm{O}$ and $\mathrm{NO}$, but also oxidizes $\mathrm{SO}_{2}$ to $\mathrm{SO}_{3}$. The generated $\mathrm{SO}_{3}$ continues to react with $\mathrm{NH}_{3}$ to generate ammonium sulfate species, thereby plugging the pores and masking the active sites, thus decreasing the activity of the SCR reaction [25]. The inevitable soot and some alkali metals in factory waste can also affect the activity of catalysts and even lead to deactivation of catalysts $[4,5,26]$. The evaluation of vanadium-based catalytic activity is shown in Figure 4. It can be seen that the $\mathrm{NO}_{\mathrm{x}}$ conversion rate of conventional catalysts is higher than $90 \%$ at $300-400{ }^{\circ} \mathrm{C}$, and has little effect 
in the presence of $\mathrm{SO}_{2}$. However, through experiments, we found that the longer the $\mathrm{SO}_{2}$ exists, the greater the decrease of catalyst activity as shown in Figure $4 \mathrm{~b}$. In this case, the performance improvement of vanadium-based catalysts has been the focus of research. In order to improve the activity of vanadium-based catalysts, the method usually has been adopted by changing the catalyst preparation, improving the performance of the support, adding modification elements and so on.
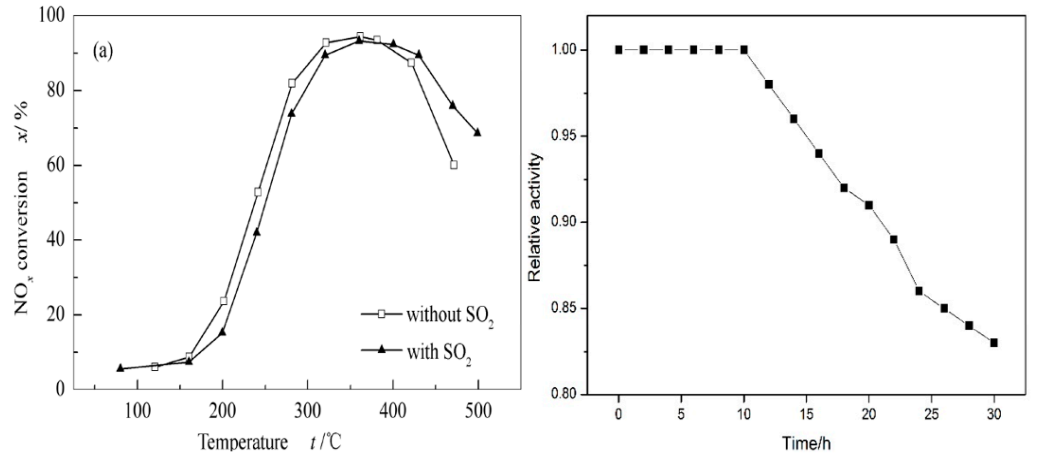

Figure 4. (a) $\mathrm{NO}_{x}$ conversion rate under different conditions [17]; (b) The relative activity of $\mathrm{SO}_{2}$ varies with time.

Usually the preparation of catalysts requires drying and calcining, and other processes. Some catalysts are activated by calcination. The calcination temperature affects the crystal structure of the catalyst. The adsorption sites and the adsorption numbers of different crystal planes are different. The surface sites' variation lie with the nature of the oxide, preparative method used, conditions of activation, and impurities [27]. At the same time, both lattice defects and inhomogeneous surfaces have an effect on the catalytic properties.

The crystal form of catalyst support has a significant influence on SCR reactions, for example, $\mathrm{TiO}_{2}$-anatase has higher dispersibility to active components than $\mathrm{TiO}_{2}$-rutile and leads to greater performance. The methods of preparing catalyst supports include impregnation, coprecipitation, hydrothermal, and sol-gel. The impregnation method is the most widely used method because of its simple and easily-operated process. These methods mainly control the particle size and morphology of the support, as well as the binding strength of active components to the support, thus affecting the dispersion of active components and the activity of the catalyst. Pappas, D.K. et al. [28] have used the alkaline hydrothermal method to prepare titanium nanotubes and co-precipitation to prepare spherical nanoparticles and nanotubes for comparison. It was found that different forms of supports have certain effects on the SCR reaction. Using titanium nanotubes as support has a better effect than spherical titanium nanoparticles. This is because the multilayer structure of the titanium nanotube can provide greater surface area to facilitate the dispersion of active components, so as to provide more active sites. Vuong, T.H. et al. prepared $\mathrm{CeO}_{2}$ supports by a citrate or a precipitation method and then got loading $\mathrm{V} / \mathrm{CeO}_{2}$ catalysts by wet impregnation. Comparing with the citrate sol-gel protocol, the mesoporous $\mathrm{CeO}_{2}$ support prepared by the precipitation method is much more active due to markedly higher surface area, higher concentration of $\mathrm{Ce}^{3+}$ bulk species and oxygen vacancies, which are beneficial for oxygen transport through the lattice [10].

Adding a modified element to modify the catalyst is beneficial to improve the performance of vanadium-based catalysts. Different modified elements may cause different effects on the $\mathrm{VO}_{\mathrm{x}}$ active sites because of different physical and chemical properties of the surface. The presence of surface acid sites depends on both the specific oxide-supported ligand and the surface density of the metal oxide overlayer [29]. At ambient conditions, vanadium species on titania has distorted the octahedral oxygen environment with one short $(\mathrm{V}=\mathrm{O})$ and one long $\mathrm{V}-\mathrm{O}$ axial bond at low loading $\mathrm{V}_{2} \mathrm{O}_{5}$ [30]. The theoretical value for monolayer coverage of dehydrated $\mathrm{VO}_{x} / \mathrm{TiO}_{2}$ catalysts is 7.9 atom $/ \mathrm{nm}^{2}$ [29]. Due to stronger interactions between vanadium and ceria, vanadium oxide species disperse on ceria up to $9 \mathrm{~V}$ atom $/ \mathrm{nm}^{2}$ of support determined by Raman Spectroscopy [31]. Vanadia reacts with cerium 
oxide to form $\mathrm{CeVO}_{4}$ phase, so two types of vanadium species $\left(\mathrm{VO}_{\mathrm{x}}\right.$ and $\left.\mathrm{CeVO}_{4}\right)$ are dispersed on the surface of cerium dioxide. $\mathrm{CeVO}_{4}$ promotes the formation of Brønsted acid sites while $\mathrm{VO}_{\mathrm{x}}$ and $\mathrm{CeO}_{2}$ provide Lewis acid sites on the surface [32]. However, the formation of Brønsted acid sites is related to vanadium species $\mathrm{VO}_{\mathrm{x}}$ in bulk $\mathrm{CeVO}_{4}$ after aging at $500{ }^{\circ} \mathrm{C}$ [18]. Therefore, the Lewis acid sites may be converted to the Brønsted acid sites at high temperature SCR reaction. In bulk $\mathrm{CeVO}_{4}$ catalysts, the isolated vanadium species in the tetrahedral coordination are basically stable after the zircon-type structure $\mathrm{CeVO}_{4}$ aging at $500{ }^{\circ} \mathrm{C}$ [18]. In the Ce-doped $\mathrm{V}_{2} \mathrm{O}_{5}-\mathrm{WO}_{3} / \mathrm{TiO}_{2}$ catalyst, the presence of $\mathrm{Ce}^{3+}$ creates a charge imbalance, vacancies, and unsaturated chemical bonds, thus increasing the chemisorbed oxygen on the surface. In addition, the coexistence of $\mathrm{Ce}^{4+}$ was found to play an important role in the synergic effect on the SCR reaction [33]. At ambient conditions for fresh $\mathrm{Fe}-\mathrm{V} / \mathrm{TiO}_{2}$ catalysts, the structures of the vanadium species exist in octahedral $(70 \%)$ and tetrahedral (30\%) coordination [34]. The acid sites on $\mathrm{V}_{2} \mathrm{O}_{5}-\mathrm{Fe}_{2} \mathrm{O}_{3} / \mathrm{TiO}_{2}$ are mainly derived from $\mathrm{Fe}_{2} \mathrm{O}_{3}-\mathrm{TiO}_{2}$, so the adsorbed $\mathrm{NH}_{3}$ prefer to be activated by $\mathrm{Fe}^{3+}$, and then $\mathrm{V}^{5+}$ accelerate the regeneration of $\mathrm{Fe}^{3+}$ [35]. In $\mathrm{FeVO}_{4} / \mathrm{TiO}_{2}$ catalysts, the $\mathrm{FeVO}_{4}$ loading amount should be less than $9 \mathrm{wt} \%$ to avoid exceeding the monolayer dispersion limit. The $\mathrm{Fe}^{3+}-\mathrm{O}-\mathrm{V}^{5+}$ linkages with a low coordination number of vanadium atoms are associated with structural defects on the surface. The presence of an electronic inductive effect between $\mathrm{Fe}^{3+}$ and $\mathrm{V}^{5+}$ was beneficial for high deNO $\mathrm{N}_{\mathrm{x}}$ efficiency and $\mathrm{N}_{2}$ selectivity [36]. At low temperatures, $\mathrm{FeVO}_{4}$ shows low activity for $\mathrm{SCR}$ in $\mathrm{FeVO}_{4} / \mathrm{TiO}_{2}-\mathrm{WO}_{3}-\mathrm{SiO}_{2}$ catalysts. However, in the decomposition of $\mathrm{FeVO}_{4}$, the $\mathrm{VO}_{x}$ species exhibits higher SCR activity. So, the active species for SCR is not $\mathrm{FeVO}_{4}$ but $\mathrm{VO}_{x}$ species [37]. The presence of iron can be useful in altering the electron density of the $\mathrm{VO}_{\mathrm{x}}$ surface species and inducing more Lewis acid sites and Brønsted acid sites for SCR reaction [38]. Currently, in the catalytic denitrification reaction of manganese-based bimetallic oxide catalysts, $\mathrm{Mn}-\mathrm{OH}$ as a Brønsted acid site adsorbs $\mathrm{NH}_{3}$ to form $\mathrm{NH}_{4}{ }^{+} . \mathrm{NH}_{4}{ }^{+}$is then reacted with $\mathrm{NO}$ to create $\mathrm{N}_{2}, \mathrm{H}_{2} \mathrm{O}$ and $\mathrm{Mn}^{3+}-\mathrm{OH}$. Finally, $\mathrm{Mn}^{3+}$ is reoxidized to regenerate $\mathrm{Mn}^{4+}$ [39]. The addition of $\mathrm{Mn}$ shows a promoting effect on the activity of the $\mathrm{V}_{2} \mathrm{O}_{5} / \mathrm{TiO}_{2}$ catalyst because manganese oxides contain various valence states, facilitating the completing of the catalytic cycle. As promoter, the ideal loading of $\mathrm{Mn}$ is about $2 \%$ for $\mathrm{V}_{2} \mathrm{O}_{5} / \mathrm{TiO}_{2}$ catalysts to avoid the oxidation of $\mathrm{NH}_{3}$ at high temperatures. The presence of the synergetic effect between $\mathrm{V}$ and $\mathrm{Mn}$ contributes the improvement of SCR activity. The redox cycle $\left(\mathrm{V}^{4+}+\mathrm{Mn}^{4+} \leftrightarrow \mathrm{V}^{5+}+\mathrm{Mn}^{3+}\right)$ reduces the energy required for electron transfer between $\mathrm{Mn}$ and $\mathrm{V}$ active sites, and promotes the adsorption and activation of $\mathrm{NH}_{3}$ and NO. $\mathrm{Mn}^{3+}$ is conducive to $\mathrm{NH}_{3}-\mathrm{SCR}$ reactions due to its ability to induce the formation of more surface chemisorbed oxygen [40]. In $\mathrm{Cu}-\mathrm{V} / \mathrm{TiO}_{2}$ catalysts, the copper species exist mainly as $\mathrm{Cu}^{2+}$ in $\mathrm{CuV}_{2} \mathrm{O}_{6}, \mathrm{Cu}_{2} \mathrm{~V}_{2} \mathrm{O}_{7}$ or $\mathrm{CuO}$. Different bimetallic copper vanadate oxides have different configurations, for example, distorted octahedral $\mathrm{VO}_{6}$ sub-units and tetrahedral $\mathrm{VO}_{4}$ sub-units. $\mathrm{VO}_{4}$ units are more convenient to access to $\mathrm{NH}_{3}$ due to their open $\mathrm{V}$ environment. By introducing copper species, strong acid sites are increased. It is worth noting that Lewis acid sites are the strong acid sites in $\mathrm{Cu}-\mathrm{V} / \mathrm{TiO}_{2}$ catalyst $[21,41]$.

The performance improvement of vanadium-based catalysts is mainly in the following two directions. The first is to widen the temperature window of vanadium-based catalysis, so that it can guarantee the activity of the medium-temperature section and have very good low-temperature activity at the same time. The second is to improve the resistance to sulfate poisoning of vanadium-based catalysts and the erosion ability of water and alkaline metals. Many researchers adopted different methods of improvement and achieved varying results.

\subsection{The Broadening of the Temperature Ranges}

In practice, the temperature of exhaust gas is about $200{ }^{\circ} \mathrm{C}$. Therefore, the broadening of the temperature range is mainly important for the low temperature section. Adding modified elements $(\mathrm{Cu}, \mathrm{Ce}, \mathrm{Fe}, \mathrm{Mn}$, etc.) is a more effective method to solve it.

The $\mathrm{Cu}$ based catalyst has good low temperature activity. It has been found that the combination of copper oxide and other metal oxides can obtain better activity. The $\mathrm{NO}_{\mathrm{x}}$ conversion rate of the 
catalyst for the $\mathrm{Cu}-\mathrm{V}$ system is described in Figure 5. It can be seen from diagram that at the optimum $\mathrm{Cu}-\mathrm{V}$ ratio, the conversion of $\mathrm{NO}_{\mathrm{x}}$ reaches $90 \%$ at $180^{\circ} \mathrm{C}$ and nearly $100 \%$ at $220^{\circ} \mathrm{C}$ [6]. The synergistic effect of $\mathrm{Cu}$ and $\mathrm{V}$ alleviated the influence of $\mathrm{VO}_{\mathrm{x}}$ aggregation on $\mathrm{TiO}_{2}$ crystal form, enhanced the adsorption capacity of the catalyst surface, and facilitated to the SCR reaction at low temperatures. However, $\mathrm{Cu}$ is conducive to forming $\mathrm{CuSO}_{4}$ with $\mathrm{SO}_{2}$, and the ability of resisting $\mathrm{SO}_{2}$ poisoning is poor $[5,26]$.

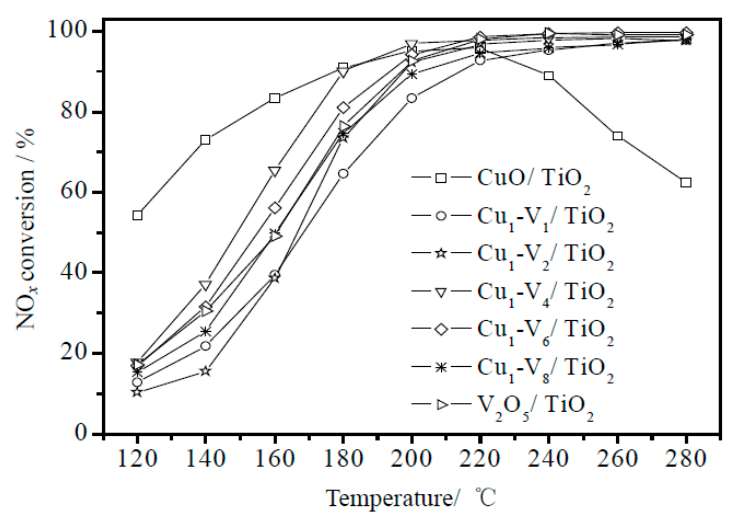

Figure 5. Conversion rate of $\mathrm{NO}_{\mathrm{x}}$ at different reaction temperatures [6].

$\mathrm{Ce}$, as a rare earth element, has been studied more in recent years. It has some kind of role of "backup chemical bond" due to the variability of the coordination number. As a modified element, it could facilitate the valence of vanadium species rapidly changing by a redox cycle of $\mathrm{V}^{5+}+\mathrm{Ce}^{3+} \leftrightarrow$ $\mathrm{V}^{4+}+\mathrm{Ce}^{4+}$. There are experiments using $\mathrm{CeVO}_{4}$ as a precursor loaded onto the support and compared with the performance of $\mathrm{V}_{2} \mathrm{O}_{5} / \mathrm{TiO}_{2}[7,18]$. It shows that the catalyst has a high catalytic activity and a wide temperature window with the best Ce content and a suitable calcination temperature (vanadate decomposition temperature). The activity evaluation of the catalyst with different calcining temperatures in fast conditions is shown in Figure 6. It exhibits that the $\mathrm{NO}_{\mathbf{x}}$ conversion rate reaches over $90 \%$ at the optimum heat treatment temperature, from $200-450{ }^{\circ} \mathrm{C}$. The calcined $\mathrm{CeVO}_{4}$ exhibited better $\mathrm{NO}$ conversion and $\mathrm{N}_{2}$ selectivity. The redox ability of Ce can increase the surface acidity of the catalyst and improve the storage capacity of oxygen. $\mathrm{Ce}^{4+} / \mathrm{Ce}^{3+}$ can form solid solutions with other oxides to increase the active sites. Meanwhile, Ce can effectively reduce the sintering tendency [7,42]. In addition, the activity distribution of $\mathrm{V}_{2} \mathrm{O}_{5} / \mathrm{CeO}_{2}$ mixed oxides is somewhat complex. The existence of $\mathrm{CeVO}_{4}$ and the correlation of the $\mathrm{V}-\mathrm{O}-\mathrm{Ce}$ subsequently constitute two systems: $\mathrm{VO}_{\mathrm{x}} / \mathrm{CeO}_{2}$ and $\mathrm{CeVO}_{4} / \mathrm{CeO}_{2}$. The coexistence of low concentration of $\mathrm{Ce}^{4+}$ species assists to enhance the rate $\mathrm{NO}$ conversion to nitrogen [18]. And the synergistic effect of two oxides of $\mathrm{CeO}_{2}$ and $\mathrm{V}_{2} \mathrm{O}_{5}$ generated by the decomposition of cerium vanadate promotes redox cycle and improves the activity of the catalyst.

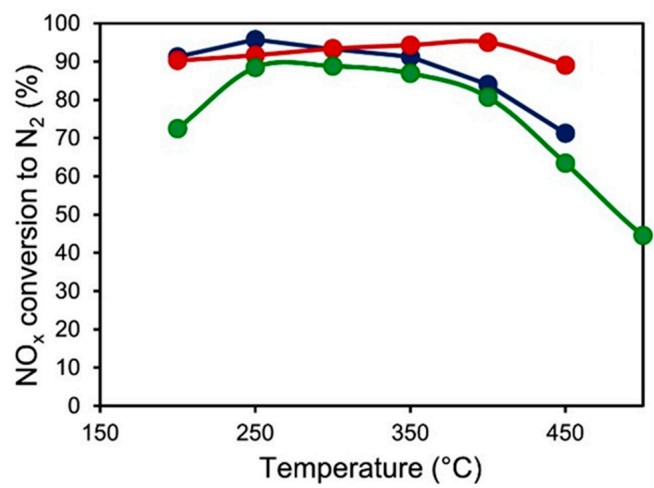

Figure 6. The activity evaluation of the catalyst at different calcining temperatures: after aging at $500{ }^{\circ} \mathrm{C}$ (full symbol in red); after aging at $600{ }^{\circ} \mathrm{C}$ (full symbol in green); fresh (full symbol in blue) Reproduced with permission [18]. Copyright 2017, Elsevier. 
Iron-based catalysts have attracted much attention because of their cheap, nontoxic, and high hydrothermal stability and $\mathrm{N}_{2}$ selectivity. But at low temperature, they exhibits a poor conversion rate of $\mathrm{NO}_{\mathrm{x}}$. In SCR reactions temperatures below $300{ }^{\circ} \mathrm{C}$, the active site of iron is mainly in the form of isolated $\mathrm{Fe}^{3+}$. When the temperature rises, oligomeric iron oxide clusters, and iron oxide particles become dominant. This contributes more to the SCR reaction and makes it more active. The introduction of Fe can increase the weak acid sites of the catalyst and the $\mathrm{NH}^{4+}$ formed by $\mathrm{NH}_{3}$ in the weak acid sites is more easily attached and activated in the SCR reaction [17]. Nickel added as a modified element could change the electronic environment of the metal surface through the formation of heteroatom bonds, thereby modifying its electronic structure with the ligand effect, improving the surface properties [43]. Wu, G. et al. [44] have conducted experiments by adding nickel to the $\mathrm{FeV} / \mathrm{Ti}$ catalyst to investigate the effect on the SCR reaction. Figure 7 shows the evaluation of the catalytic activity of different catalysts in the $\mathrm{Fe}-\mathrm{Ni}-\mathrm{V}$ system. It can be seen that, with the optimum proportion, the catalytic activity of $\mathrm{NO}_{x}$ reaches over $90 \%$ at $250-550{ }^{\circ} \mathrm{C}$, and the $\mathrm{NO}_{x}$ conversion rate at $280-500{ }^{\circ} \mathrm{C}$ reaches $100 \%$. The results show that Ni promotes the interaction between $\mathrm{FeVO}_{4}$ nanoparticles and $\mathrm{TiO}_{2}$, and improves the acidity and reducing activity. When the content of $\mathrm{Ni}$ is $0-0.4$, $\mathrm{Ni}$ is highly dispersed on the surface of $\mathrm{FeVO}_{4}$. When the content is $0.6-1$, Ni reacts with $\mathrm{FeVO}_{4}$ to form nickel-iron spinel, so that more defects and oxygen vacancies are formed on the surface of the catalyst. The addition of Ni affects the grain size, changes the surface properties of the catalyst, has better activity at the test temperature, and can widen the temperature window.

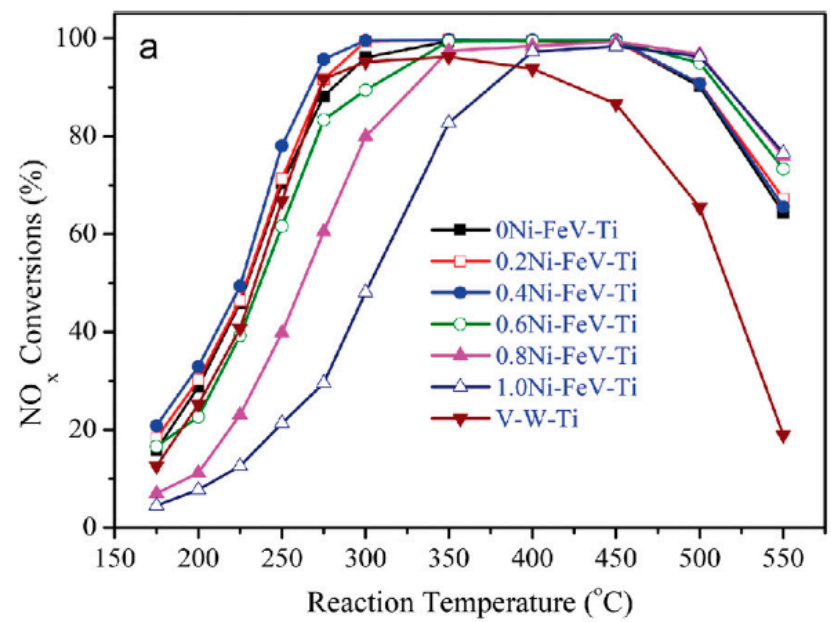

Figure 7. Catalytic activity evaluation of different catalysts in $\mathrm{Fe}-\mathrm{Ni}-\mathrm{V}$ system. Reproduced with permission [44]. Copyright 2017, Elsevier.

Manganese bases have attracted attention due to their high activity at low temperatures. The crystalline phase structure of the manganese-based catalysts prepared by different methods can affect the reactivity of SCR, and the irregular surface structure causes more defects and active sites, thus increasing the reactivity of SCR. Liu, J. et al. [45] have studied the SCR reaction mechanism of manganese-based catalysts and believe that the highly active manganese reacts mainly according to the $\mathrm{L}-\mathrm{H}$ reaction mechanism at low temperature. Pure $\mathrm{MnO}_{\mathrm{x}}$ is unsuitable as a catalyst because of its low surface area and poor thermal stability [46]. However, manganese-based catalysts have lower $\mathrm{N}_{2}$ selectivity, and are easily deactivated under $\mathrm{SO}_{2}$ and $\mathrm{H}_{2} \mathrm{O}$ conditions, causing irreversible loss of oxidation ability, resulting in the blockage of pores and active sites by ammonium sulfate salts, limiting the further popularization. Therefore, Zheng, Z. et al. [47] utilize the excellent low-temperature performance of $\mathrm{MnO}_{\mathrm{x}}$ to make up for the shortcoming of the narrow temperature window of $\mathrm{V}_{2} \mathrm{O}_{5} / \mathrm{TiO}_{2}$ and prepare an $\mathrm{Mn}-\mathrm{V}-\mathrm{Ce} / \mathrm{TiO}_{2}$ catalyst. This catalyst uses $\mathrm{Mn}$ to provide low-temperature active sites, and $\mathrm{Ce}$ and $\mathrm{V}$ provide sufficient oxygen vacancies while enhancing the surface acidity, thereby significantly improving the low-temperature activity. As shown in Figure 8, the activity of 
$\mathrm{Mn}-\mathrm{V}-\mathrm{Ce} / \mathrm{TiO}_{2}$ catalyst at different temperatures is evaluated. It is found that the $\mathrm{NO}_{\mathrm{x}}$ conversion rate is as high as $99.2 \%$ at $150{ }^{\circ} \mathrm{C}$, indicating excellent low-temperature activity of the catalyst.

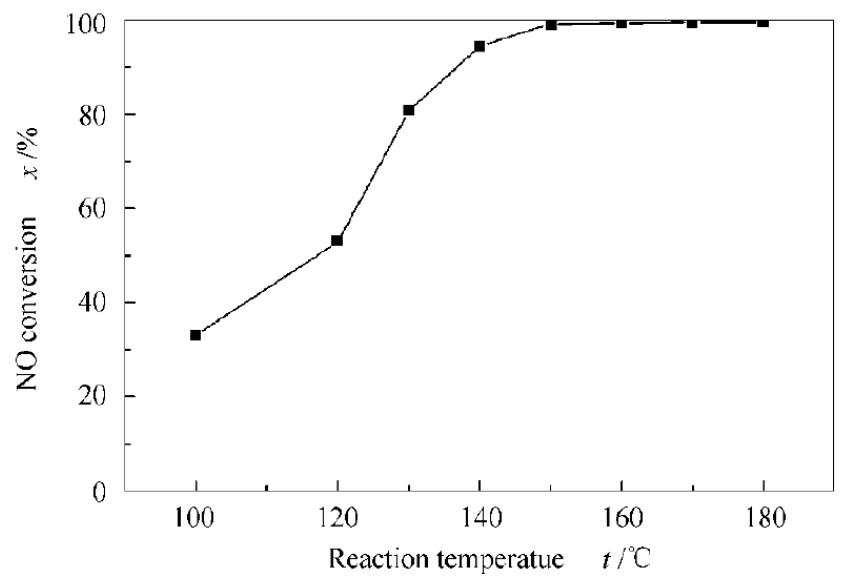

Figure 8. Activity evaluation of $\mathrm{Mn}-\mathrm{V}-\mathrm{Ce} / \mathrm{TiO}_{2}$ catalysts at different temperatures [47].

\subsection{The Improvement of Erosion Resistance}

$\mathrm{V}_{2} \mathrm{O}_{5}-\mathrm{WO}_{3}\left(\mathrm{MoO}_{3}\right) / \mathrm{TiO}_{2}$, which has been put into industrial use, is subjected to a lot of erosion in the actual industry environment, one of which is high concentrations of $\mathrm{SO}_{2} \cdot \mathrm{V}_{2} \mathrm{O}_{5}$ possesses $\mathrm{SO}_{2}$ durability, but $\mathrm{SO}_{3}$ is generated due to peroxidation, and the resulting sulfuric acid (hydrogen) salt will affect the catalyst activity. The addition of $\mathrm{WO}_{3}$ is helpful to increase the Brønsted acid sites, enhance the reaction activity by improving the redox capacity at low temperatures, and to restrain the phase transition, but it still faces erosion of hydrogen sulfate. Li, C. et al. [48] studied the formation and decomposition of ammonium bisulfate over $\mathrm{V}_{2} \mathrm{O}_{5}-\mathrm{WO}_{3} / \mathrm{TiO}_{2}$ catalysts at different temperatures. With the combination of ammonium hydrogen sulfate (ABS) and metal oxides $\left(\mathrm{WO}_{3}\right.$ and $\mathrm{TiO}_{2}$ ), electrons deviate from the sulfate, thereby weakening the stability of the ABS and reducing the decomposition temperature. However, the vanadium-generated intermediate $\mathrm{VOSO}_{4}$ makes the sulphate electrons saturated. The presence of $\mathrm{NO}$ and $\mathrm{O}_{2}$ could break the bonds inside the ABS, and react with the ammonia species produced in it, allowing the $\mathrm{NH}_{3}$ to be separated from the ABS, accelerating the decomposition of the $\mathrm{ABS}$ and competing to inhibit its formation. It was found that the trace $\mathrm{ABS}$ on $\mathrm{TiO}_{2}$ had little effect on the $\mathrm{NH}_{3}$-SCR reaction at $300^{\circ} \mathrm{C}$. Under $300{ }^{\circ} \mathrm{C}$, sulfuric acid (hydrogen) ammonia species cover the active sites, masking $\mathrm{VOSO}_{4}$ intermediate products, resulting in a poor $\mathrm{NH}_{3}-\mathrm{SCR}$ reaction performance. Therefore, it is necessary to study the $\mathrm{SO}_{2}$ corrosion resistance of catalysts applied to low temperature.

Compared with $\mathrm{WO}_{3}, \mathrm{MoO}_{3}$ is less affected by $\mathrm{SO}_{2}$ and the chemical properties of $\mathrm{MoO}_{3}$ are similar to those of $\mathrm{WO}_{3}$. Kwon, D.W. et al. [49] have used ammonium molybdate $\left(\mathrm{NH}_{4}\right)_{2} \mathrm{MoO}_{4}$ and ammonium heptamolybdate $\left(\mathrm{NH}_{4}\right)_{2} \mathrm{Mo}_{2} \mathrm{O}_{7}$ as precursors of molybdenum sources, and ammonium metatungstate hydrates as precursors for tungsten sources, compared with $\mathrm{WO}_{3}$ and $\mathrm{MoO}_{3}$ properties, to study $\mathrm{MoO}_{3}$ 's ability of resisting $\mathrm{SO}_{2}$. The catalyst was characterized by $\mathrm{X}$-ray photoelectron spectroscopy (XPS) analysis, and the results showed that the binding energy of ammonium heptamolybdate was higher than that of ammonium molybdate. High binding energy can promote the interaction of metal atoms and oxygen, which is beneficial to the redox and SCR reactions of $\mathrm{NO}_{\mathrm{x}}$. Furthermore, the $\mathrm{Mo}^{6+} / \mathrm{Mo}^{5+}$ of ammonium heptamolybdate is higher than that of ammonium molybdate. The presence of $\mathrm{Mo}^{6+}$ on the surface of the catalyst can inhibit the reaction between $\mathrm{SO}_{2}$ and $\mathrm{V}=\mathrm{O}$, reduce the absorption of $\mathrm{SO}_{2}$, and thus play the role of resisting $\mathrm{SO}_{2}$. Therefore, high $\mathrm{Mo}^{6+} / \mathrm{Mo}^{5+}$ exhibits excellent resistance to $\mathrm{SO}_{2}$. Figure 9 shows relative activity in the presence of $\mathrm{SO}_{2}$ for the SCR of $\mathrm{NO}$ by $\mathrm{NH}_{3}$ over different catalysts at $250{ }^{\circ} \mathrm{C}$. It can be seen that the $\mathrm{SO}_{2}$ has a certain effect on the catalyst. However, compared to the $\mathrm{V}_{2} \mathrm{O}_{5} / \mathrm{TiO}_{2}$ and the $\mathrm{V}_{2} \mathrm{O}_{5} / \mathrm{WO}_{3}$ system, the time for $\mathrm{V}_{2} \mathrm{O}_{5} / \mathrm{MoO}_{3}$ to remain active is more prolonged. That is, $\mathrm{V}_{2} \mathrm{O}_{5} / \mathrm{MoO}_{3}$ is more resistant to $\mathrm{SO}_{2}$. 


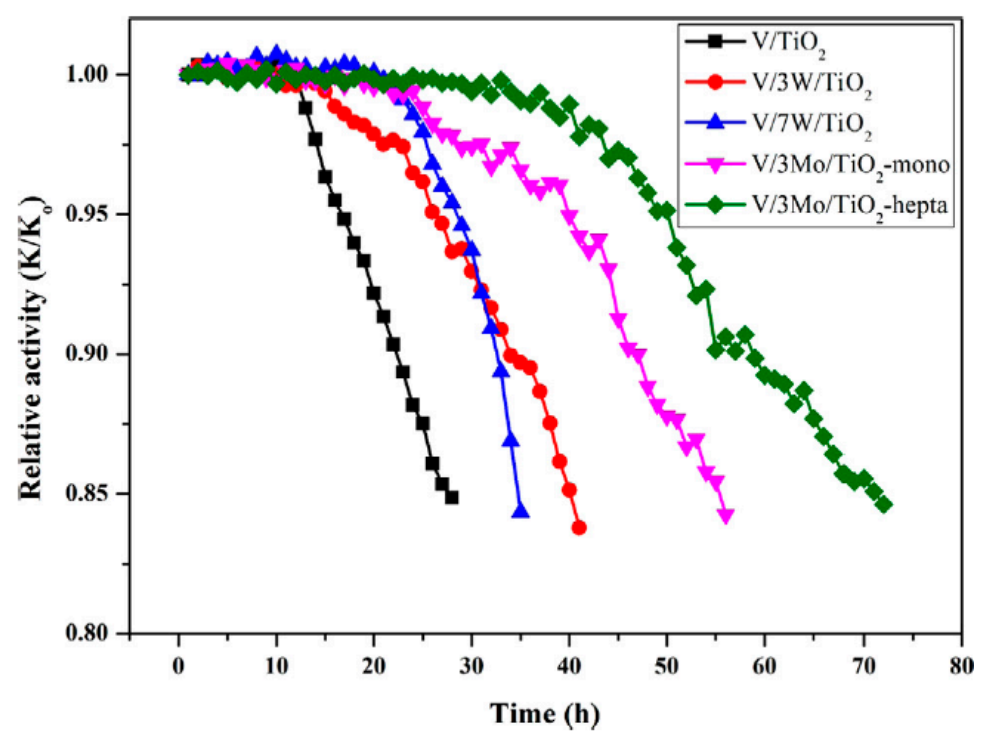

Figure 9. Relative activity in the presence of $\mathrm{SO}_{2}$ for the SCR of $\mathrm{NO}$ by $\mathrm{NH}_{3}$ over $\mathrm{V} / \mathrm{TiO}_{2}$, $\mathrm{V} / 3 \mathrm{~W} / \mathrm{TiO}_{2}, \mathrm{~V}-3 \mathrm{Mo} / \mathrm{TiO}_{2}-\mathrm{mono}$ and $\mathrm{V} / 3 \mathrm{Mo} / \mathrm{TiO}_{2}$-hepta at $250{ }^{\circ} \mathrm{C}$. Reproduced with permission [49]. Copyright 2016, Elsevier.

It is important to note that, when testing against $\mathrm{SO}_{2}$ toxicity, the controlled erosion conditions are only $\mathrm{SO}_{2}$. However, in practical applications, the emitted gas may contain a certain amount of water vapor. At this point, $\mathrm{SO}_{2}$ and $\mathrm{H}_{2} \mathrm{O}, \mathrm{NH}_{3}$ more easily form ammonium sulfate on the surface of the catalyst to deactivate the catalyst. Generally, at temperatures between 200 and $300{ }^{\circ} \mathrm{C}$, vanadium-based catalyst SCR reactions are strongly affected by coordination of water. The adsorbed ammonia on oxo vanadia Lewis acid sites and ammonium ions associated with Brønsted acid sites selective reduce weakly adsorbed NO via the E-R mechanism, and the water appears to shift the equilibrium between $\mathrm{NH}_{3}$ and $\mathrm{NH}_{4}{ }^{+}$. At this time, the ratio between Lewis acid, Brønsted acid sites and $\mathrm{V}=\mathrm{O}$ sites depend on the content of water vapor [15]. Because of the low $\mathrm{SO}_{2}$ resistance of $\mathrm{V}_{2} \mathrm{O}_{5}-\mathrm{WO}_{3} / \mathrm{TiO}_{2}$, there are experiments showing that selecting $\mathrm{Ce}$ to replace $\mathrm{V}$ and the prepared $\mathrm{Ce}_{0.2} \mathrm{~W}_{0.2} \mathrm{TiOx}$ has good $\mathrm{NOx}$ conversion activity and $\mathrm{N}_{2}$ selectivity [42]. The activity of the catalyst was stable under the condition of $\mathrm{SO}_{2}$ only, while the decrease of the activity of the catalyst was observed under the condition of both $\mathrm{SO}_{2}$ and $\mathrm{H}_{2} \mathrm{O}$. In addition, the performance of the $\mathrm{Fe}_{1} \mathrm{~V}_{1} / \mathrm{TiO}_{2}$ catalyst was tested with an aqueous test and anhydrous test, as shown in Figure 10, and the results showed that the activity in the anhydrous test was obviously better than that of the water test [17]. Based on this, it is necessary to discharge the prior drying or improve the resistance of the catalyst to water erosion performance.

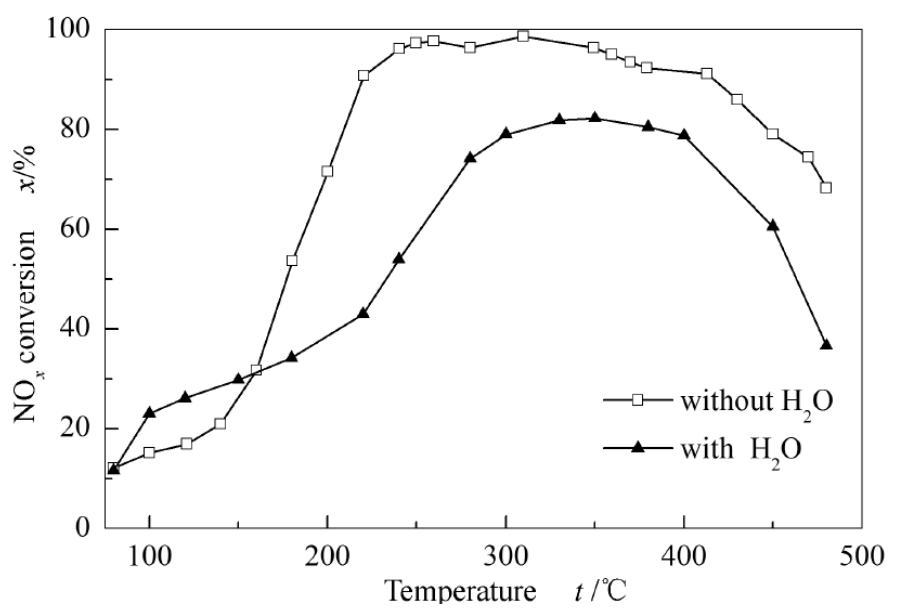

Figure 10. The effect of water vapor on $\mathrm{NO}_{\mathrm{x}}$ conversion of $\mathrm{Fe}_{1} \mathrm{~V}_{1} / \mathrm{TiO}_{2}$ catalyst [17]. 
In addition, the actual application of high-temperature exhaust gas may be in some alkaline environment, and the catalyst may suffer alkali poisoning. Chen, L. et al. [50] have investigated the effects that alkali metals and alkaline earth metals may have on catalysts. It was found that the degree of poisoning of the catalyst increased with the increase of alkalinity, and the $\mathrm{N}_{2} \mathrm{O}$ conversion rate decreased with the increase of alkaline content. The toxic element occupies the non-atomic pore site of the $\mathrm{V}_{2} \mathrm{O}_{5}$ [010] plane, so that the Brønsted acid and $\mathrm{V}^{5+}=\mathrm{O}$ sites are blocked. In alkali metals such as $\mathrm{Na}$, K will reduce the stability of Brønsted acid sites, reduce the absorption of ammonia, and reduce the amount of surface chemically adsorbed oxygen. By contrast, the effect of alkaline earth metals such as $\mathrm{Ca}$ and $\mathrm{Mg}$ on the reducibility of $\mathrm{V}$ is not obvious. $\mathrm{Hu}$, W. et al. [51] have prepared $\mathrm{V}-\mathrm{Ce}\left(\mathrm{SO}_{4}\right)_{2} / \mathrm{Ti}$ catalysts, utilizing the high oxygen storage ability and strong redox ability of $\mathrm{Ce}$, and sulfate $\mathrm{SO}_{4}{ }^{2-}$ that can increase surface acidity to obtain better performance by synergizing $\mathrm{Ce}$ with $\mathrm{SO}_{4}{ }^{2-}$. Ce introduces a high proportion of surface-active oxygen to increase the redox capacity of the catalyst. The abundant $\mathrm{NO}^{+}$and $\mathrm{NO}^{3-}$ on the surface form a redox cycle. The catalyst has better resistance to $\mathrm{SO}_{2}, \mathrm{H}_{2} \mathrm{O}$, and alkali metal than the vanadium-based commercial catalyst. Gao et al. [52] used sulfided zirconia as a catalyst support and added Ce:V $=1: 1$ to obtain a $\operatorname{CeVSZ}(\mathrm{x})$ catalyst. The support provides too many acidic sites to react with the alkali metal and delay the acidity reduction. $\mathrm{V}$ partially replaces Ce to form $\mathrm{CeVO}_{4}$, avoiding $\mathrm{CeO}_{2}$ from being converted into $\mathrm{Ce}_{2}\left(\mathrm{SO}_{4}\right)_{3}$ to make it permanently inactivated. The CeVSZ(x) catalyst can maintain activity higher than $97 \%$ in the atmosphere of $\mathrm{SO}_{2}$ and $\mathrm{K}$ coexistence, and there is no significant decrease in activity within $400 \mathrm{~min}$. Huang, Z. et al. [53] prepared a hexagonal structure of $\mathrm{WO}_{3}(\mathrm{HWO})$ as a support to load $\mathrm{V}_{2} \mathrm{O}_{5}$. The corner-sharing $\mathrm{WO}_{6}$ octahedra form hexagonal tunnels oriented along the $\mathrm{C}$-axis with space group $\mathrm{P} 6 / \mathrm{mmm}$, and the external surface of HWO allows $\mathrm{V}_{2} \mathrm{O}_{5}$ to be highly dispersed. The tunnels have relatively smooth surfaces and suitable sizes for alkalis' trapping specifically. Alkalis are readily inserted into tunnels by ion exchange reaction, so $\mathrm{HWO}$ has excellent resistance to alkali metal erosion. Figure 11 shows the catalytic activity evaluation of the $\mathrm{V}_{2} \mathrm{O}_{5} / \mathrm{HWO}$ catalyst and the $\mathrm{V}_{2} \mathrm{O}_{5} / \mathrm{WO}_{3}-\mathrm{TiO}_{2}$ catalyst at $350{ }^{\circ} \mathrm{C}$ under a gas containing $\mathrm{NO}, \mathrm{NH}_{3}, \mathrm{SO}_{2}$ and alkali metal particles. It can be seen that the activity of $\mathrm{V}_{2} \mathrm{O}_{5} / \mathrm{HWO}$ is much higher than that of $\mathrm{V}_{2} \mathrm{O}_{5} / \mathrm{WO}_{3}-\mathrm{TiO}_{2}$ catalysts under the coexistence of $\mathrm{SO}_{2}$ and alkali metal.

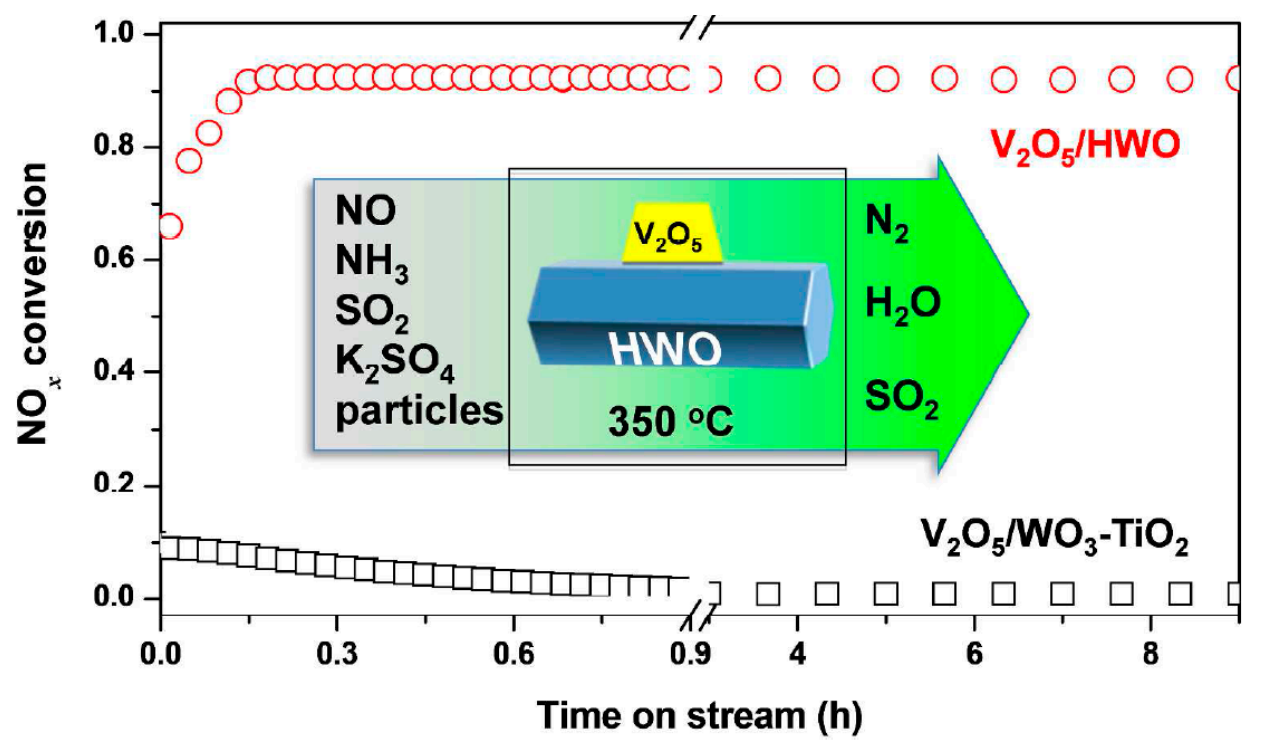

Figure 11. Activity evaluation of $\mathrm{V}_{2} \mathrm{O}_{5} / \mathrm{HWO}$ catalyst and $\mathrm{V}_{2} \mathrm{O}_{5} / \mathrm{WO}_{3}-\mathrm{TiO}_{2}$ catalyst at $350{ }^{\circ} \mathrm{C}$. Reproduced with permission [53]. Copyright 2015, American Chemical Society.

\section{Conclusions and Perspective}

The vanadium-based catalyst is the most mature catalyst, and has a high catalytic activity at medium temperatures. However, considering the thermal instability of vanadium, the low-temperature 
catalytic demand, and severe working environment in industrial production, the improvement of vanadium-based catalysts has become a research hotspot. The most common improvement method is in the modification of vanadium-based catalysts. Four major systems of cerium, iron, copper and manganese are widely used in this field. Cerium has excellent ability to store and release oxygen. The redox cycle is realized by $\mathrm{Ce}^{3+} / \mathrm{Ce}^{4+}$ electron pairs, which provide oxygen vacancy and active sites and enhance the activity of catalysts. $\mathrm{CeVO}_{4}$ stabilizes the surface $\mathrm{V}^{5+}$ species, accelerates redox cycle and $\mathrm{NO}_{2}$ production, and helps to spur fast $\mathrm{SCR}$. The cooperative effect between Ce and $\mathrm{V}$ leads to the enhancement of SCR activity. The presence of $\mathrm{Ce}^{3+} / \mathrm{Ce}^{4+}$ increases surface chemisorbed oxygen and provide more acid sites. $\mathrm{CeVO}_{4}$ promotes the formation of Brønsted acid sites while $\mathrm{VO}_{\mathrm{x}}$ and $\mathrm{CeO}_{2}$ provide Lewis acid sites on the surface. In addition, the Lewis acid sites may be converted to the Brønsted acid sites at high temperature SCR reactions. However, Ce is prone to generate $\mathrm{Ce}_{2}\left(\mathrm{SO}_{4}\right)_{3}$ with sulfate to cause permanent deactivation of the catalyst. At low temperatures, the unrivaled, high-activity of manganese-based oxides and copper-based oxides can significantly broaden the temperature window of vanadium-based catalysts, though they have poor low-temperature erosion resistance. The redox cycle $\left(\mathrm{V}^{4+}+\mathrm{Mn}^{4+} \leftrightarrow \mathrm{V}^{5+}+\mathrm{Mn}^{3+}\right)$ reduces the energy required for electron transfer between $\mathrm{Mn}$ and $\mathrm{V}$ active sites, and promotes the adsorption and activation of $\mathrm{NH}_{3}$ and $\mathrm{NO}$. $\mathrm{Mn}^{3+}$ is conducive to $\mathrm{NH}_{3}-\mathrm{SCR}$ reactions because it induces the formation of more surface chemisorbed oxygen. By introducing copper species, strong acid sites are increased. It is worth noting that Lewis acid sites are the strong acid sites in $\mathrm{Cu}-\mathrm{V} / \mathrm{TiO}_{2}$ catalysts. Iron is cheap and nontoxic material with high hydrothermal stability. Due to the presence of $\mathrm{Fe}^{3+}-\mathrm{O}-\mathrm{V}^{5+}$ linkages, $\mathrm{FeVO}_{4}$ incorporate a lot of surface defects which can adsorb or activate reactants. The adsorbed $\mathrm{NH}_{3}$ prefers to be activated by $\mathrm{Fe}^{3+}$ due to the rapid electron transfer. The presence of electronic inductive effect between $\mathrm{Fe}^{3+}$ and $\mathrm{V}^{5+}$ was beneficial for high deNO $\mathrm{x}_{\mathrm{x}}$ efficiency and $\mathrm{N}_{2}$ selectivity. The $\mathrm{VO}_{\mathrm{x}}$ species, the decomposition product of $\mathrm{FeVO}_{4}$, exhibits higher SCR activity as active component. The presence of iron can be useful by altering the electron density of the $\mathrm{VO}_{\mathrm{x}}$ surface species and inducing more Lewis acid sites and Brønsted acid sites for SCR reactions.

Although the research on denitrification catalysts has attracted widespread attention, the mechanism of SCR reaction is not yet clear. Research on the resistance of $\mathrm{SO}_{2}, \mathrm{H}_{2} \mathrm{O}$, and alkali metals has made some progress, but there is still a lack of research on its inhibition mechanism. With the increasing importance of environmental protection, the development of vanadium-based catalysts is a general trend. Further study is expected to realize on the catalysis mechanism of synergistic effect and the performance optimization.

Author Contributions: Conceptualization, J.Z., X.L., P.C. and B.Z.; investigation, J.Z.; data analysis, X.L., P.C. and B.Z.; writing—original draft preparation, J.Z.; writing—review and editing, X.L., B.Z.; financial support, X.L., B.Z.

Acknowledgments: The authors would like to thank the financial support of Natural Science Foundation of China (Gant No. 51774182 and 51602231).

Conflicts of Interest: The authors declare no conflict of interest.

\section{References}

1. Bendrich, M.; Scheuer, A.; Hayes, R.E.; Votsmeier, M. Unified mechanistic model for standard SCR, fast SCR, and $\mathrm{NO}_{2}$ SCR over a copper chabazite catalyst. Appl. Catal. B Environ. 2018, 222, 76-87. [CrossRef]

2. Zhu, M.H.; Lai, J.K.; Tumuluri, U.; Ford, M.E.; Wu, Z.L.; Wachs, I.E. Reaction pathways and kinetics for selective catalytic reduction (SCR) of acidic $\mathrm{NO}_{x}$ emissions from power plants with $\mathrm{NH}_{3}$. ACS Catal. 2017, 7, 8358-8361. [CrossRef]

3. Liu, F.D.; Shan, W.; Shi, X.; He, H. Vanadium-based catalysts for the selective catalytic reduction of $\mathrm{NO}_{\mathrm{x}}$ with $\mathrm{NH}_{3}$. Prog. Chem. 2012, 24, 445-455. (In Chinese)

4. Luo, S.P.; Zhou, W.T.; Xie, A.J.; Wu, F.Q.; Yao, C.; Li, X.Z.; Zuo, S.X.; Liu, T.H. Effect of $\mathrm{MnO}_{2}$ polymorphs structure on the selective catalytic reduction of $\mathrm{NO}_{x}$ with $\mathrm{NH}_{3}$ over $\mathrm{TiO}_{2}$-Palygorskite. Chem. Eng. J. 2016, 286, 291-299. (in Chinese). [CrossRef] 
5. Liu, T.; Wang, T.C.; Wu, R.Q.; Shen, B.X. Research advance review for low-temperature $\mathrm{NH}_{3}$-SCR catalysts. J. Saf. Environ. 2012, 19, 42-44. (in Chinese).

6. Huang, H.F.; Jin, L.L.; Zhang, H.H.; Yu, H.; Lu, H.F. Preparation and characterization of $\mathrm{Cu}^{-V}-\mathrm{TiO}_{2}$ catalysts with strong resistance to $\mathrm{SO}_{2}$ for low-temperature SCR of $\mathrm{NO}_{x}$. J. Chem. Eng. Chin. Univ. 2013, 27, 721-728. (In Chinese)

7. Marberger, A.; Ferri, D.; Elsener, M.; Sagar, A.; Artner, C.; Schermanz, K.; Krocher, O. Relationship between structures and activities of supported metal vanadates for the selective catalytic reduction of $\mathrm{NO}$ by $\mathrm{NH}_{3}$. Appl. Catal. B Environ. 2017, 218, 731-742. [CrossRef]

8. Cheng, J.; Song, Y.; Ye, Q.; Cheng, S.Y.; Kang, T.F.; Dai, H.X. A mechanistic investigation on the selective catalytic reduction of NO with ammonia over the V-Ce/Ti-PILC catalysts. Mol. Catal. 2018, 445, 111-123. [CrossRef]

9. Yang, W.W.; Liu, F.D.; Xie, L.J.; Lian, Z.H.; He, H. Effect of $\mathrm{V}_{2} \mathrm{O}_{5}$ additive on the $\mathrm{SO}_{2}$ resistance of a $\mathrm{Fe}_{2} \mathrm{O}_{3} / \mathrm{AC}$ catalyst for $\mathrm{NH}_{3}-\mathrm{SCR}$ of $\mathrm{NO}_{x}$ at low temperatures. Ind. Eng. Chem. Res. 2016, 55, 2677-2685. [CrossRef]

10. Vuong, T.H.; Radnik, J.; Schneider, M.; Atia, H.; Armbruster, U.; Brückner, A. Effect of support synthesis methods on structure and performance of $\mathrm{VO}_{\mathrm{x}} \mathrm{CeO}_{2}$ catalysts in low-temperature $\mathrm{NH}_{3}-\mathrm{SCR}$ of $\mathrm{NO}$. Catal. Commun. 2016, 84, 171-174. [CrossRef]

11. Vuong, T.H.; Radnik, J.; Kondratenko, E.; Schneider, M.; Armbruster, U.; Brückner, A. Structure-reactivity relationships in $\mathrm{VO}_{\mathrm{x}} \mathrm{Ce}_{\mathrm{x}} \mathrm{Zr}_{1-\mathrm{x}} \mathrm{O}_{2}$ catalysts used for low-temperature $\mathrm{NH}_{3}$-SCR of NO. Appl. Catal. B Environ. 2016, 197, 159-167. [CrossRef]

12. He, Y.Y.; Ford, M.E.; Zhu, M.H.; Liu, Q.C.; Tumuluri, U.; Wu, Z.L.; Wachs, I.E. Influence of catalyst synthesis method on selective catalytic reduction (SCR) of $\mathrm{NO}$ by $\mathrm{NH}_{3}$ with $\mathrm{V}_{2} \mathrm{O}_{5}-\mathrm{WO}_{3} \mathrm{TiO}_{2}$ catalysts. Appl. Catal. B Environ. 2016, 193, 141-150. [CrossRef]

13. Tao, P.; Sun, M.H.; Qu, S.C.; Song, C.W.; Li, C.; Yin, Y.Y.; Cheng, M.R. Effects of $\mathrm{V}_{2} \mathrm{O}_{5}$ and $\mathrm{WO}_{3}$ loadings on the catalytic performance of $\mathrm{V}_{2} \mathrm{O}_{5}-\mathrm{WO}_{3} \mathrm{TiO}_{2}$ catalyst for SCR of $\mathrm{NO}$ with $\mathrm{NH}_{3}$. Glob. NEST 2017, 19, 160-166.

14. Marberger, A.; Elsener, M.; Ferri, D.; Krocher, O. $\mathrm{VO}_{\mathrm{x}}$ surface coverage optimization of $\mathrm{V}_{2} \mathrm{O}_{5} / \mathrm{WO}_{3}-\mathrm{TiO}_{2}$ SCR catalysts by variation of the $\mathrm{v}$ loading and by aging. Catalysts 2015, 5, 1704-1720. [CrossRef]

15. Rasmussen, S.B.; Portela, R.; Bazin, P.; Avila, P.; Banares, M.A.; Daturi, M. Transient operando study on the $\mathrm{NH}_{3} / \mathrm{NH}_{4}{ }^{+}$interplay in V-SCR monolithic catalysts. Appl. Catal. B Environ. 2018, 224, 109-115. [CrossRef]

16. Giakoumelou, I.; Fountzoula, C.; Kordulis, C.; Boghosian, S. Molecular structure and catalytic activity of $\mathrm{V}_{2} \mathrm{O}_{5} / \mathrm{TiO}_{2}$, catalysts for the $\mathrm{SCR}$ of $\mathrm{NO}$ by $\mathrm{NH}_{3}$ : In situ Raman spectra in the presence of $\mathrm{O}_{2}, \mathrm{NH}_{3}, \mathrm{NO}, \mathrm{H}_{2}$, $\mathrm{H}_{2} \mathrm{O}$, and $\mathrm{SO}_{2}$. J. Catal. 2006, 239, 1-12. [CrossRef]

17. Huang, H.F.; Chen, Y.J.; Yang, R.; Zhu, Q.L.; Lu, H.F. Fe-V/ $\mathrm{TiO}_{2}$ catalysts for selective catalytic reduction of $\mathrm{NO}_{x}$ with $\mathrm{NH}_{3}$ in diesel exhaust. J. Fuel Chem. Technol. 2014, 42, 751-757. (In Chinese)

18. Gillot, S.; Tricot, G.; Vezin, H.; Dacquin, J.-P.; Dujardin, C.; Granger, P. Development of stable and efficient $\mathrm{CeVO}_{4}$ systems for the selective reduction of $\mathrm{NO}_{\mathrm{x}}$ by ammonia: Structure-activity relationship. Appl. Catal. B Environ. 2017, 218, 338-348. [CrossRef]

19. Zhou, X.M.; Huang, X.Y.; Xie, A.J.; Luo, S.P.; Yao, C.; Li, X.Z.; Zuo, S.X. $\mathrm{V}_{2} \mathrm{O}_{5}$-decorated Mn-Fe/attapulgite catalyst with high $\mathrm{SO}_{2}$ tolerance for SCR of $\mathrm{NO}_{x}$ with $\mathrm{NH}_{3}$ at low temperature. Chem. Eng. J. 2017, 326, 1074-1085. [CrossRef]

20. Choo, S.T.; Lee, Y.G.; Nam, I.S.; Ham, S.W.; Lee, J.B. Characteristics of $\mathrm{V}_{2} \mathrm{O}_{5}$, supported on sulfated $\mathrm{TiO}_{2}$, for selective catalytic reduction of $\mathrm{NO}$ by $\mathrm{NH}_{3}$. Appl. Catal. A Gen. 2000, 200, 177-188. [CrossRef]

21. Kim, J.; Kwon, D.W.; Lee, S.; Ha, H.P. Exploration of surface properties of Sb-promoted copper vanadate catalysts for selective catalytic reduction of $\mathrm{NO}_{X}$ by $\mathrm{NH}_{3}$. Appl. Catal. B Environ. 2018, 236, 314-325. [CrossRef]

22. Topsoe, N.Y.; Dumesic, J.A.; Topsoe, H. Vanadia-titania catalysts for selective catalytic reduction of nitric-oxide by ammonia: I.I. studies of active sites and formulation of catalytic cycles. J. Catal. 1995, 151, 241-252. [CrossRef]

23. Nova, I.; Tronconi, E. Kinetic study of the $\mathrm{NO} / \mathrm{NO}_{2}-\mathrm{NH}_{3} \mathrm{SCR}$ reactions over a $\mathrm{V}_{2} \mathrm{O}_{5}-\mathrm{WO}_{3} / \mathrm{TiO}_{2}$ commercial catalyst for the after treatment of diesel engines exhausts. Engine Powertrain Control Simul. Model. 2009, 32, 183-190. [CrossRef] 
24. Yun, D.M.; Wang, Y.; Herrera, J.E. Ethanol partial oxidation over $\mathrm{VO}_{\mathrm{x}} / \mathrm{TiO}_{2}$ catalysts: The role of Titania surface oxygen on vanadia reoxidation in the mars-van krevelen mechanism. ACS Catal. 2018, 8, 4681-4693. [CrossRef]

25. Youn, S.; Song, I.; Lee, H.; Cho, S.J.; Kim, D.H. Effect of pore structure of $\mathrm{TiO}_{2}$ on the $\mathrm{SO}_{2}$ poisoning over $\mathrm{V}_{2} \mathrm{O}_{5} / \mathrm{TiO}_{2}$ catalysts for selective catalytic reduction of $\mathrm{NO}_{x}$ with $\mathrm{NH}_{3}$. Catal. Today 2018, 303, $19-24$. [CrossRef]

26. Zhuang, F.L.; Liu, S.H.; Lin, W.S.; Chen, Y.; Chen, C.W. Research progress in low vanadium and non-vanadium oxide catalysts for the selective catalytic reduction by $\mathrm{NH}_{3}$. Environ. Eng. 2016, 34, 98-102. (In Chinese)

27. Dunn, J.P.; Stenger, H.G., Jr.; Wachs, I.E. Oxidation of sulfur dioxide over supported vanadia catalysts: molecular structure-reactivity relationships and reaction kinetics. Catal. Today 1999, 51, 301-308. [CrossRef]

28. Pappas, D.K.; Boningari, T.; Boolchand, P.; Smirniotis, P.G. Novel manganese oxide confined interweaved titania nanotubes for the low-temperature selective catalytic reduction (SCR) of $\mathrm{NO}_{x}$ by $\mathrm{NH}_{3}$. J. Catal. 2016, 334, 1-13. [CrossRef]

29. Wachs, I.E. Raman and IR studies of surface metal oxide species on oxide supports: Supported metal oxide catalysts. Catal. Today 1996, 27, 437-455. [CrossRef]

30. Nielsen, U.G.; Topsoe, N.Y.; Brorson, M.; Skibated, J.; Jakobsen, H.J. The complete ${ }^{51}$ V MAS NMR spectrum of surface vanadia nanoparticles on anatase $\left(\mathrm{TiO}_{2}\right)$ : Vanadia surface structure of a DeNO $\mathrm{X}_{\mathrm{x}}$ catalyst. J. Am. Chem. Soc. 2004, 126, 4926-4933. [CrossRef] [PubMed]

31. Martinez-Huerta, M.V.; Coronado, J.M.; Fernandez-Garcia, M.; Iglesias-Juez, A.; Deo, J.; Fierro, J.L.G.; Banares, M.A. Nature of the vanadia-ceria interface in $\mathrm{V}^{5+} / \mathrm{CeO}_{2}$ catalysts and its relevance for the solid-state reaction toward $\mathrm{CeVO}_{4}$ and catalytic properties. J. Catal. 2004, 225, 240-248. [CrossRef]

32. Peng, Y.; Wang, C.; Li, J. Structure-activity relationship of $\mathrm{VO}_{\mathrm{x}} / \mathrm{CeO}_{2}$ nanorod for $\mathrm{NO}$ removal with ammonia. Appl. Catal. B Environ. 2014, 144, 538-546. [CrossRef]

33. Chen, L.; Li, J.; Ge, M. Promotional effect of Ce-doped $\mathrm{V}_{2} \mathrm{O}_{5}-\mathrm{WO}_{3} / \mathrm{TiO}_{2}$ with low vanadium loadings for selective catalytic reduction of $\mathrm{NO}_{x}$ by $\mathrm{NH}_{3}$. J. Phys. Chem. C 2009, 113, 21177-21184. [CrossRef]

34. Haggblad, R.; Massa, M.; Andersson, A. Stability and performance of supported Fe-V-oxide catalysts in methanol oxidation. J. Catal. 2009, 266, 218-227. [CrossRef]

35. Yang, S.; Wang, C.; Ma, L.; Peng, Y.; Qu, Z.; Yan, N.; Chen, J.; Chang, H.; Li, J. Substitution of $\mathrm{WO}_{3}$ in $\mathrm{V}_{2} \mathrm{O}_{5} / \mathrm{WO}_{3}-\mathrm{TiO}_{2}$ by $\mathrm{Fe}_{2} \mathrm{O}_{3}$ for selective catalytic reduction of $\mathrm{NO}$ with $\mathrm{NH}_{3}$. Catal. Sci. Technol. 2013, 3, 161-168. [CrossRef]

36. Liu, F.; He, H.; Lian, Z.; Shan, W.; Xie, L.; Asakura, K.; Yang, W.; Deng, H. Highly dispersed iron vanadate catalyst supported on $\mathrm{TiO}_{2}$ for the selective catalytic reduction of $\mathrm{NO}_{x}$ with $\mathrm{NH}_{3}$. J. Catal. 2013, 307, 340-351. [CrossRef]

37. Marberger, A.; Elsener, M.; Ferri, D.; Sagar, A.; Schermanz, K.; Krocher, O. Generation of $\mathrm{NH}_{3}$ selective catalytic reduction active catalysts from decomposition of supported $\mathrm{FeVO}_{4}$. ACS Catal. 2015, 5, 4180-4188. [CrossRef]

38. Casanova, M.; Nodari, L.; Sagar, A.; Schermanz, K.; Trovarelli, A. Preparation, characterization and $\mathrm{NH}_{3}-\mathrm{SCR}$ activity of $\mathrm{FeVO}_{4}$ supported on $\mathrm{TiO}_{2}-\mathrm{WO}_{3}-\mathrm{SiO}_{2}$. Appl. Catal. B Environ. 2015, 176, 699-708. [CrossRef]

39. Zhang, L.; Wen, X.; Lei, Z.; Gao, L.; Sha, X.; Ma, Z.; He, H.; Wang, Y.; Jia, Y.; Li, Y. Study on the mechanism of a manganese-based catalyst for catalytic $\mathrm{NO}_{\mathrm{x}}$ flue gas denitration. AIP Adv. 2018, 8, 045004. [CrossRef]

40. Liu, Z.; Li, Y.; Zhu, T.; Su, H.; Zhu, J. Selective catalytic reduction of $\mathrm{NO}_{x}$ by $\mathrm{NH}_{3}$ over Mn-promoted $\mathrm{V}_{2} \mathrm{O}_{5} / \mathrm{TiO}_{2}$ catalyst. Ind. Eng. Chem. Res. 2014, 53, 12964-12970. [CrossRef]

41. Zhao, X.; Huang, L.; Li, H.; Hu, H.; Han, J.; Shi, L.; Zhang, D. Highly dispersed $\mathrm{V}_{2} \mathrm{O}_{5} / \mathrm{TiO}_{2}$, modified with transition metals $(\mathrm{Cu}, \mathrm{Fe}, \mathrm{Mn}, \mathrm{Co})$ as efficient catalysts for the selective reduction of $\mathrm{NO}$ with $\mathrm{NH}_{3}$. Chin. J. Catal. 2015, 36, 1886-1899. [CrossRef]

42. Shan, W.P.; Liu, F.D.; He, H.; Shi, X.Y.; Zhang, C.B. A superior Ce-W-Ti mixed oxide catalyst for the selective catalytic reduction of $\mathrm{NO}_{x}$ with $\mathrm{NH}_{3}$. Appl. Catal. B Environ. 2012, 115, 100-106. [CrossRef]

43. De, S.; Zhang, J.G.; Luque, R.; Yan, N. Ni-based bimetallic heterogeneous catalysts for energy and environmental applications. Energy Environ. Sci. 2016, 9, 3314-3347. [CrossRef]

44. Wu, G.; Feng, X.; Zhang, H.; Zhang, Y.; Wang, J.; Chen, Y.; Dan, Y. The promotional role of $\mathrm{Ni}_{\text {in }} \mathrm{FeVO}_{4}$ $/ \mathrm{TiO}_{2}$ monolith catalyst for selective catalytic reduction of $\mathrm{NO}_{x}$ with $\mathrm{NH}_{3}$. Appl. Surf. Sci. 2018, 427, $24-36$. [CrossRef] 
45. Liu, J.; Li, X.Y.; Li, R.Y.; Zhao, Q.D.; Ke, J.; Xiao, H.N.; Wang, L.D.; Liu, S.M.; Tade, M.; Wang, S.B. Facile synthesis of tube-shaped Mn-Ni-Ti solid solution and preferable Langmuir-Hinshelwood mechanism for selective catalytic reduction of $\mathrm{NO}_{x}$ by $\mathrm{NH}_{3}$. Appl. Catal. A Gen. 2018, 549, 289-301. [CrossRef]

46. Sun, P.; Guo, R.T.; Liu, S.M.; Wang, S.X.; Pan, W.G.; Li, M.Y. The enhanced performance of $\mathrm{MnO}_{\mathrm{x}}$ catalyst for $\mathrm{NH}_{3}$-SCR reaction by the modification with Eu. Appl. Catal. A Gen. 2017, 531, 129-138. [CrossRef]

47. Zheng, Z.H.; Tong, H.; Tong, Z.Q.; Huang, Y.; Luo, J. Catalytic reduction of NO over Mn-V-Ce/TiO 2 catalysts at low reaction temperature. J. Fuel Chem. Technol. 2010, 38, 343-351. (In Chinese)

48. Li, C.X.; Shen, M.Q.; Yu, T.; Wang, J.Q.; Wang, J.; Zhai, Y.P. The mechanism of ammonium bisulfate formation and decomposition over $\mathrm{V} / \mathrm{WTi}$ catalysts for $\mathrm{NH}_{3}$-selective catalytic reduction at various temperatures. Phys. Chem. Chem. Phys. 2017, 19, 15194-15206. [CrossRef] [PubMed]

49. Kwon, D.W.; Park, K.H.; Hong, S.C. Enhancement of SCR activity and $\mathrm{SO}_{2}$ resistance on $\mathrm{VO}_{\mathrm{x}} / \mathrm{TiO}_{2}$ catalyst by addition of molybdenum. Chem. Eng. J. 2016, 284, 315-324. [CrossRef]

50. Chen, L.; Li, J.H.; Ge, M. The poisoning effect of alkali metals doping over nano $\mathrm{V}_{2} \mathrm{O}_{5}-\mathrm{WO}_{3} / \mathrm{TiO}_{2}$ catalysts on selective catalytic reduction of $\mathrm{NO}_{x}$ by $\mathrm{NH}_{3}$. Chem. Eng. J. 2011, 170, 531-537. [CrossRef]

51. Hu, W.S.; Zhang, Y.H.; Liu, S.J.; Zheng, C.H.; Gao, X.; Nova, I.; Tronconi, E. Improvement in activity and alkali resistance of a novel $\mathrm{V}-\mathrm{Ce}\left(\mathrm{SO}_{4}\right)_{2}$ / Ti catalyst for selective catalytic reduction of $\mathrm{NO}$ with $\mathrm{NH}_{3}$. Appl. Catal. B Environ. 2017, 206, 449-460. [CrossRef]

52. Gao, S.; Wang, P.L.; Yu, F.X.; Wang, H.Q.; Wu, Z.B. Dual resistance to alkali metals and $\mathrm{SO}_{2}$ : Vanadium and cerium supported on sulfated zirconia as an efficient catalyst for $\mathrm{NH}_{3}$-SCR. Catal. Sci. Technol. 2016, 6, 8148-8156. [CrossRef]

53. Huang, Z.W.; Li, H.; Gao, J.Y.; Gu, X.; Zheng, L.; Hu, P.P.; Xin, Y.; Chen, J.X.; Chen, Y.X.; Zhang, Z.L.; et al. Alkali- and sulfur-resistant tungsten-based catalysts for $\mathrm{NO}_{\mathrm{x}}$ emissions control. Environ. Sci. Technol. 2015, 49, 14460-14465. [CrossRef] [PubMed]

(C) 2018 by the authors. Licensee MDPI, Basel, Switzerland. This article is an open access article distributed under the terms and conditions of the Creative Commons Attribution (CC BY) license (http:/ / creativecommons.org/licenses/by/4.0/). 